4

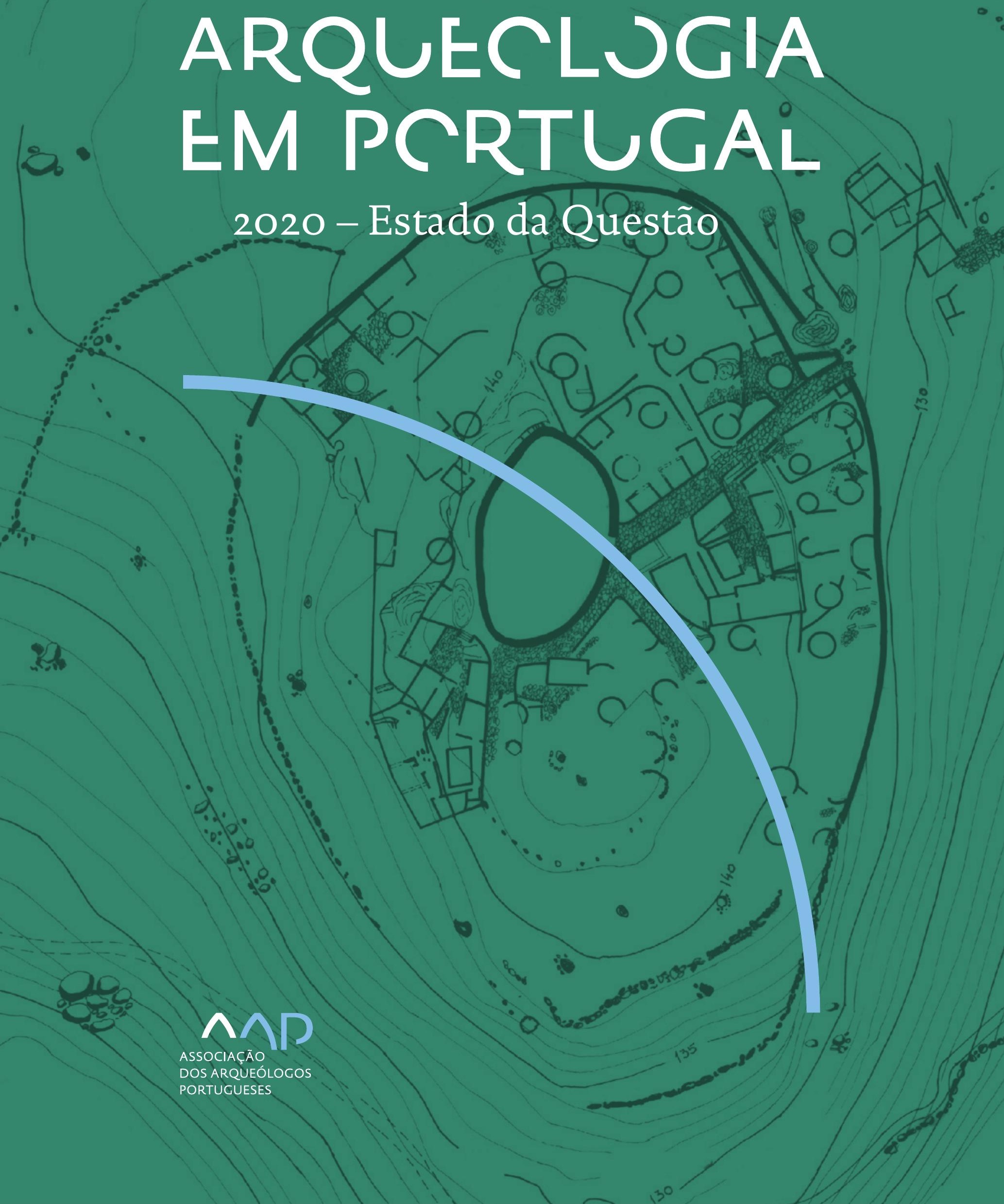


Coordenação editorial: José Morais Arnaud, César Neves e Andrea Martins Design gráfico: Flatland Design

AAP - ISBN: 978-972-9451-89-8

CITCEM - ISBN: 978-989-8970-25-1

Associação dos Arqueólogos Portugueses e CITCEM

Lisboa, 2020

O conteúdo dos artigos é da inteira responsabilidade dos autores. Sendo assim a Associação dos Arqueólogos Portugueses declina qualquer responsabilidade por eventuais equívocos ou questões de ordem ética e legal.

Desenho de capa:

Planta do castro de Monte Mozinho (Museu Municipal de Penafiel).

\section{$\hat{\wedge} \mathrm{P}$}

DOS ARQUEÓLOGOS PORTUGUESES

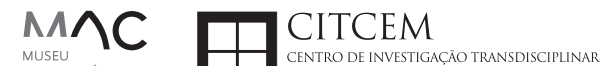
MUSEU
ARQUELLÓGICO
DO CARMO
U.PORTO

FLUP FACULDADE DE LETRAS
UNIVERSIDADE DO PORTO

Apoio

EC para a Ciência 


\section{Índice}

15 Prefácio

José Morais Arnaud

\section{Historiografia e Teoria}

17 Território, comunidade, memória e emoção: a contribuição da história da arqueologia (algumas primeiras e breves reflexões)

Ana Cristina Martins

25 Como descolonizar a arqueologia portuguesa?

Rui Gomes Coelho

41 Arqueologia e Modernidade: uma revisitação pessoal e breve de alguns aspetos da obra homónima de Julian Thomas de 2004

Vítor Oliveira Jorge

57 Dados para a História das Mulheres na Arqueologia portuguesa, dos finais do século XIX aos inícios do século XX: números, nomes e tabelas

Filipa Dimas / Mariana Diniz

73 Retractos da arqueologia portuguesa na imprensa: (in)visibilidades no feminino

Catarina Costeira / Elsa Luís

85 Arqueologia e Arqueólogos no Norte de Portugal Jacinta Bugalhão

101 Vieira Guimarães (1864-1939) e a arqueologia em Tomar: uma abordagem sobre o território e as gentes

João Amendoeira Peixoto / Ana Cristina Martins

115 Os memoráveis? A arqueologia algarvia na imprensa nacional e regional na presente centúria (2001-2019): características, visões do(s) passado(s) e a arqueologia

enquanto marca

Frederico Agosto / João Silva

129 A Evolução da Arqueologia Urbana e a Valorização Patrimonial no Barlavento Algarvio: Os casos de Portimão e Silves

Artur Mateus / Diogo Varandas / Rafael Boavida

\section{Gestão, Valorização e Salvaguarda do Património}

145 O Caderno Reivindicativo e as condições de trabalho em Arqueologia Miguel Rocha / Liliana Matias Carvalho / Regis Barbosa / Mauro Correia / Sara Simões / Jacinta Bugalhão / Sara Brito / Liliana Veríssimo Carvalho / Richard Peace / Pedro Peça / Cézer Santos

155 Os Estudos de Impacte Patrimonial como elemento para uma estratégia sustentável de minimização de impactes no âmbito de reconversões agrícolas Tiago do Pereiro

165 Salvaguarda de Património arqueológico em operações florestais: gestão e sensibilização Filipa Bragança / Gertrudes Zambujo / Sandra Lourenço / Belém Paiva / Carlos Banha / Frederico Tatá Regala / Helena Moura / Jacinta Bugalhão / João Marques / José Correia / Pedro Faria / Samuel Melro

179 Os valores do Património: uma investigação sobre os Sítios Pré-históricos de Arte Rupestre do Vale do Rio Côa e de Siega Verde José Paulo Francisco 
189 Conjugando recursos arqueológicos e naturais para potenciar as visitas ao Geoparque Litoral de Viana do Castelo (Noroeste de Portugal)

Hugo A. Sampaio / Ana M.S. Bettencourt / Susana Marinho / Ricardo Carvalhido

203 Áreas de Potencial Arqueológico na Região do Médio Tejo: Modelo Espacial Preditivo Rita Ferreira Anastácio / Ana Filipa Martins / Luiz Oosterbeek

223 Património Arqueológico e Gestão Territorial: O contributo da Arqueologia para a revisão do PDM de Avis

Ana Cristina Ribeiro

237 A coleção arqueológica do extinto Museu Municipal do Porto - Origens, Percursos e Estudos

Sónia Couto

251 Valpaços - uma nova carta arqueológica

Pedro Pereira / Maria de Fátima Casares Machado

263 Arqueologia na Cidade de Peniche

Adriano Constantino / Luís Rendeiro

273 Arqueologia Urbana: a cidade de Lagos como caso de Estudo Cátia Neto

285 Estratégias de promoção do património cultural subaquático nos Açores. O caso da ilha do Faial

José Luís Neto / José Bettencourt / Luís Borges / Pedro Parreira

297 Carta Arqueológica da Cidade Velha: Uma primeira abordagem

Jaylson Monteiro / Nireide Tavares / Sara da Veiga / Claudino Ramos / Edson Brito /

Carlos Carvalho / Francisco Moreira / Adalberto Tavares

311 Antropologia Virtual: novas metodologias para a análise morfológica e funcional Ricardo Miguel Godinho / Célia Gonçalves

\section{Didáctica da Arqueologia}

327 Como os projetos de Arqueologia podem contribuir para uma comunidade culturalmente mais consciente Alexandra Figueiredo / Claúdio Monteiro / Adolfo Silveira / Ricardo Lopes

337 Educação Patrimonial - Um cidadão esclarecido é um cidadão ativo! Ana Paula Almeida

351 A aproximação da Arqueologia à sala de aula: um caso de estudo no $3^{\circ}$ ciclo do Ensino Básico Luís Serrão Gil

363 Arqueologia 3.o - Pensar e comunicar a Arqueologia para um futuro sustentável Mónica Rolo

377 “Conversa de Arqueólogos" - Divulgar a Arqueologia em tempos de Pandemia Diogo Teixeira Dias

389 Escola Profissional de Arqueologia: desafios e oportunidades Susana Nunes / Dulcineia Pinto / Júlia Silva / Ana Mascarenhas

399 Os Museus de Arqueologia e os Jovens: a oferta educativa para o público adolescente Beatriz Correia Barata / Leonor Medeiros

411 O museu universitário como mediador entre a ciência e a sociedade: o exemplo da secção de arqueologia no Museu de História Natural e da Ciência da Universidade do Porto (MHNC-UP)

Rita Gaspar 
421 Museu de Lanifícios: Real Fábrica de Panos. Atividades no âmbito da Arqueologia Beatriz Correia Barata / Rita Salvado

427 Arqueologia Pública e o caso da localidade da Mata (Torres Novas) Cláudia Manso / Ana Rita Ferreira / Cristiana Ferreira / Vanessa Cardoso Antunes

431 Do sítio arqueológico ao museu: um percurso (também) didático Lídia Fernandes

447 Estão todos convidados para a Festa! E para dançar também... O projecto do Serviço Educativo do Museu Arqueológico do Carmo na $5^{\underline{a}}$ Edição da Festa da Arqueologia Rita Pires dos Santos

459 O “Clã de Carenque”, um projeto didático de arqueologia Eduardo Gonzalez Rocha

469 Mediação cultural: peixe que puxa carroça nas Ruínas Romanas de Troia Inês Vaz Pinto / Ana Patrícia Magalhães / Patrícia Brum / Filipa Santos

481 Didática Arqueológica, experiências do Projeto Mértola Vila Museu Maria de Fátima Palma / Clara Rodrigues / Susana Gómez / Lígia Rafael

\section{Arte Rupestre}

497 Os inventários de arte rupestre em Portugal Mila Simões de Abreu

513 O projeto FIRST-ART - conservação, documentação e gestão das primeiras manifestações de arte rupestre no Sudoeste da Península Ibérica: as grutas do Escoural e Maltravieso Sara Garcês / Hipólito Collado / José Julio García Arranz / Luiz Oosterbeek / António Carlos Silva / Pierluigi Rosina / Hugo Gomes / Anabela Borralheiro Pereira / George Nash / Esmeralda Gomes / Nelson Almeida / Carlos Carpetudo

523 Trabalhos de documentação de arte paleolítica realizados no âmbito do projeto PalæoCôa André Tomás Santos / António Fernando Barbosa / Luís Luís / Marcelo Silvestre / Thierry Aubry

537 Imagens fantasmagóricas, silhuetas elusivas: as figuras humanas na arte do Paleolítico Superior da região do Côa Mário Reis

$55^{1}$ Os motivos zoomórficos representados nas placas de tear de Vila Nova de São Pedro (Azambuja, Portugal) Andrea Martins / César Neves / José M. Arnaud / Mariana Diniz

571 Arte Rupestre do Monte de Góios (Lanhelas, Caminha). Síntese dos resultados dos trabalhos efectuados em 2007-2009 Mário Varela Gomes

599 Gravuras rupestres de barquiformes no Monte de S. Romão, Guimarães, Noroeste de Portugal Daniela Cardoso

613 Círculos segmentados gravados na Bacia do Rio Lima (Noroeste de Portugal): contributos para o seu estudo Diogo Marinho / Ana M.S. Bettencourt / Hugo Aluai Sampaio

631 Equídeos gravados no curso inferior do Rio Mouro, Monção (NW Portugal). Análise preliminar Coutinho, L.M. / Bettencourt, A.M.S / Sampaio, Hugo A.S

645 Paletas na Arte Rupestre do Noroeste de Portugal. Inventário preliminar Bruna Sousa Afonso / Ana M. S. Bettencourt / Hugo A. Sampaio 


\section{Pré-História}

661 O projeto Miño/Minho: balanço de quatro anos de trabalhos arqueológicos Sérgio Monteiro-Rodrigues / João Pedro Cunha-Ribeiro / Eduardo Méndez-Quintas / Carlos Ferreira / Pedro Xavier / José Meireles / Alberto Gomes / Manuel Santonja / Alfredo Pérez-González

677 A ocupação paleolítica da margem esquerda do Baixo Minho: a indústria lítica do sítio de Pedreiras 2 (Monção, Portugal) e a sua integração no contexto regional Carlos Ferreira / João Pedro Cunha-Ribeiro / Sérgio Monteiro-Rodrigues / Eduardo Méndez-Quintas / Pedro Xavier / José Meireles / Alberto Gomes / Manuel Santonja / Alfredo Pérez-González

693 O sítio acheulense do Plistocénico médio da Gruta da Aroeira Joan Daura / Montserrat Sanz / Filipa Rodrigues / Pedro Souto / João Zilhão

703 As sociedades neandertais no Barlavento algarvio: modelos preditivos com recurso aos SIG

Daniela Maio

715 A utilização de quartzo durante o Paleolítico Superior no território dos vales dos rios Vouga e Côa

Cristina Gameiro / Thierry Aubry / Bárbara Costa / Sérgio Gomes / Luís Luís / Carmen Manzano / André Tomás Santos

733 Uma perspetiva diacrónica da ocupação do concheiro do Cabeço da Amoreira (Muge, Portugal) a partir da tecnologia lítica Joana Belmiro / João Cascalheira / Célia Gonçalves

745 Novos dados sobre a Pré-história Antiga no concelho de Palmela. A intervenção arqueológica no sítio do Poceirão I

Michelle Teixeira Santos

757 Problemas em torno de Datas Absolutas Pré-Históricas no Norte do Alentejo Jorge de Oliveira

771 Povoamento pré-histórico nas áreas montanhosas do NO de Portugal: o Abrigo 1 de Vale de Cerdeira Pedro Xavier / José Meireles / Carlos Alves

783 Apreciação do povoamento do Neolítico Inicial na Baixa Bacia do Douro. A Lavra I (Serra da Aboboreira) como caso de estudo Maria de Jesus Sanches

797 O Processo de Neolitização na Plataforma do Mondego: os dados do Sector C do Outeiro dos Castelos de Beijós (Carregal do Sal)

João Carlos de Senna-Martinez / José Manuel Quintã Ventura / Andreia Carvalho / Cíntia Maurício

823 Novos trabalhos na Lapa da Bugalheira (Almonda, Torres Novas) Filipa Rodrigues / Pedro Souto / Artur Ferreira / Alexandre Varanda / Luís Gomes / Helena Gomes / João Zilhão

837 A pedra polida e afeiçoada do sítio do Neolítico médio da Moita do Ourives (Benavente, Portugal)

César Neves

857 Casal do Outeiro (Encarnação, Mafra): novos contributos para o conhecimento do povoamento do Neolítico final na Península de Lisboa.

Cátia Delicado / Carlos Maneira e Costa / Marta Miranda / Ana Catarina Sousa

873 Stresse infantil, morbilidade e mortalidade no sítio arqueológico do Neolítico Final/ Calcolítico ( $4^{\circ}$ e $3^{\circ}$ milénio a.C.) do Monte do Carrascal 2 (Ferreira do Alentejo, Beja) Liliana Matias de Carvalho / Sofia N. Wasterlain 
885 Come together: O Conjunto Megalítico das Motas (Monção, Viana do Castelo) e as expressões Campaniformes do Alto Minho Ana Catarina Basílio / Rui Ramos

899 Trabalhos arqueológicos no sítio Calcolítico da Pedreira do Poio Carla Magalhães / João Muralha / Mário Reis / António Batarda Fernandes

913 O sítio arqueológico de Castanheiro do Vento. Da arquitectura do sítio à arquitectura de um território João Muralha Cardoso

925 Estudo zooarqueológico das faunas do Calcolítico final de Vila Nova de São Pedro (Azambuja, Portugal): Campanhas de 2017 e 2018 Cleia Detry / Ana Catarina Francisco / Mariana Diniz / Andrea Martins / César Neves / José Morais Arnaud

943 As faunas depositadas no Museu Arqueológico do Carmo provenientes de Vila Nova de São Pedro (Azambuja): as campanhas de 1937 a 1967 Ana Catarina Francisco / Cleia Detry / César Neves / Andrea Martins / Mariana Diniz / José Morais Arnaud

959 Análise funcional de material lítico em sílex do castro de Vila Nova de S. Pedro (Azambuja, Portugal): uma primeira abordagem Rafael Lima

971 O recinto da Folha do Ouro 1 (Serpa) no contexto dos recintos de fossos calcolíticos alentejanos

António Carlos Valera / Tiago do Pereiro / Pedro Valério / António M. Monge Soares

\section{Proto-História}

987 Produção de sal marinho na Idade do Bronze do noroeste Português. Alguns dados para uma reflexão

Ana M. S. Bettencourt / Sara Luz / Nuno Oliveira / Pedro P. Simões / Maria Isabel C. Alves / Emílio Abad-Vidal

1001 A estátua-menir do Pedrão ou de São Bartolomeu do Mar (Esposende, noroeste de Portugal) no contexto arqueológico da fachada costeira de entre os rios Neiva e Cávado Ana M. S. Bettencourt / Manuel Santos-Estévez / Pedro Pimenta Simões / Luís Gonçalves

1015 O Castro do Muro (Vandoma/Baltar, Paredes) - notas para uma biografia de ocupação da Idade do Bronze à Idade Média

Maria Antónia D. Silva / Ana M. S. Bettencourt / António Manuel S. P. Silva / Natália Félix

1031 Do Bronze Final à Idade Média - continuidades e hiatos na ocupação de Povoados em Oliveira de Azeméis João Tiago Tavares / Adriaan de Man

1041 As faunas do final da Idade do Bronze no Sul de Portugal: leituras desde o Outeiro do Circo (Beja)

Nelson J. Almeida / Íris Dias / Cleia Detry / Eduardo Porfírio / Miguel Serra

1055 A Espada do Monte das Oliveiras (Serpa) - uma arma do Bronze Pleno do Sudoeste Rui M. G. Monge Soares / Pedro Valério / Mariana Nabais / António M. Monge Soares

1065 São Julião da Branca (Albergaria-a-Velha) - Investigação e valorização de um povoado do Bronze Final

António Manuel S. P. Silva / Paulo A. P. Lemos / Sara Almeida e Silva / Edite Martins de Sá

1083 Do castro de S. João ao Mosteiro de Santa Clara: notícia de uma intervenção arqueológica, em Vila do Conde Rui Pinheiro 
1095 O castro de Ovil (Espinho), um quarto de século de investigação - resultados e questões em aberto

Jorge Fernando Salvador / António Manuel S. P. Silva

1111 O Castro de Salreu (Estarreja), um povoado proto-histórico no litoral do Entre Douro e Vouga

Sara Almeida e Silva / António Manuel S. P. Silva / Paulo A. P. Lemos / Edite Martins de Sá

1127 Castro de Nossa Senhora das Necessidades (Sernancelhe): uma primeira análise artefactual Telma Susana O. Ribeiro

${ }_{1141}$ A cividade de Bagunte. O estado atual da investigação Pedro Brochado de Almeida

1153 Zoomorfos na cerâmica da Idade do Ferro no NW Peninsular: inventário, cronologias e significado Nuno Oliveira / Cristina Seoane

1163 Vasos gregos em Portugal: diferentes maneiras de contar a história do intercâmbio cultural na Idade do Ferro

Daniela Ferreira

1175 Os exotica da necrópole da Idade do Ferro do Olival do Senhor dos Mártires (Alcácer do Sal) no seu contexto regional

Francisco B. Gomes

\section{Antiguidade Clássica e Tardia}

1191 O uso de madeira como combustível no sítio da Quinta de Crestelos (Baixo Sabor): da Idade do Ferro à Romanização Filipe Vaz / João Tereso / Sérgio Simões Pereira / José Sastre / Javier Larrazabal Galarza / Susana Cosme / José António Pereira / Israel Espi

1207 Cultivos de Época Romana no Baixo Sabor: continuidade em tempos de mudança? João Pedro Tereso / Sérgio Simões Pereira / Filipe Santos / Luís Seabra / Filipe Vaz

1221 A casa romana na Hispânia: aplicação dos modelos itálicos nas províncias ibéricas Fernanda Magalhães / Diego Machado / Manuela Martins

1235 As pinturas murais romanas da Rua General Sousa Machado, n. ${ }^{5}$ 1, Chaves José Carvalho

1243 Trás do Castelo (Vale de Mir, Pegarinhos, Alijó) - Uma exploração agrícola romana do Douro

Tony Silvino / Pedro Pereira

1255 A sequência de ocupação no quadrante sudeste de Bracara Augusta: as transformações de uma unidade doméstica Lara Fernandes / Manuela Martins

1263 Os Mosaicos com decoração geométrica e geométrico-vegetalista dos sítios arqueológicos da área do Conuentus Bracaraugustanus. Novas abordagens quanto à conservação, restauro, decoração e datação Maria de Fátima Abraços / Licínia Wrench

1277 “Casa Romana” do Castro de São Domingos (Cristelos, Lousada): Escavação, Estudo e Musealização Paulo André de P. Lemos

1291 A arqueobotânica no Castro de Guifões (Matosinhos, Noroeste de Portugal): O primeiro estudo carpológico

Luís Seabra / Andreia Arezes / Catarina Magalhães / José Varela / João Pedro Tereso 
1305 Um Horreum Augustano na Foz do Douro (Monte do Castelo de Gaia, Vila Nova de Gaia) Rui Ramos

1311 Ponderais romanos na Lusitânia: padrões, formas, materiais e contextos de utilização Diego Barrios Rodríguez

1323 Um almofariz centro-itálico na foz do Mondego

Marco Penajoia

1335 Estruturas romanas de Carnide - Lisboa Luísa Batalha / Mário Monteiro / Guilherme Cardoso

1347 O contexto funerário do sector da "necrópole NO" da Rua das Portas de S. Antão (Lisboa): o espaço, os artefactos, os indivíduos e a sua interconectividade na interpretação do passado Sílvia Loja, José Carlos Quaresma, Nelson Cabaço, Marina Lourenço, Sílvia Casimiro, Rodrigo Banha da Silva, Francisca Alves-Cardoso

${ }_{1361}$ Povoamento em época Romana na Amadora - resultados de um projeto pluridisciplinar Gisela Encarnação / Vanessa Dias

1371 A Arquitectura Residencial em Mirobriga (Santiago do Cacém): contributo a partir de um estudo de caso Filipe Sousa / Catarina Felício

${ }_{1385}$ O fim do ciclo. Saneamento e gestão de resíduos nos edifícios termais de Mirobriga (Santiago do Cacém)

Catarina Felício / Filipe Sousa

1399 Balsa, Topografia e Urbanismo de uma Cidade Portuária Vítor Silva Dias / João Pedro Bernardes / Celso Candeias / Cristina Tété Garcia

1413 No Largo das Mouras Velhas em Faro (2017): novas evidências da necrópole norte de Ossonoba e da sua ocupação medieval Ricardo Costeira da Silva / Paulo Botelho / Fernando Santos / Liliana Nunes

1429 Instrumentos de pesca recuperados numa fábrica de salga em Ossonoba (Faro) Inês Rasteiro / Ricardo Costeira da Silva / Paulo Botelho

1439 A Necrópole Romana do Eirô, Duas Igrejas (Penafiel): intervenção arqueológica de 2016 Laura Sousa / Teresa Soeiro

1457 Ritual, descarte ou afetividade? A presença de Canis lupus familiaris na Necrópole Noroeste de Olisipo (Lisboa)

Beatriz Calapez Santos / Sofia Simões Pereira / Rodrigo Banha da Silva / Sílvia Casimiro / Cleia Detry / Francisca Alves Cardoso

1467 Dinâmicas económicas em Bracara na Antiguidade Tardia Diego Machado / Manuela Martins / Fernanda Magalhães / Natália Botica

1479 Cerâmicas e Vidros da Antiguidade Tardia do Edifício sob a Igreja do Bom Jesus (Vila Nova de Gaia) Joaquim Filipe Ramos

1493 Novos contributos para a topografia histórica de Mértola no período romano e na Antiguidade Tardia Virgílio Lopes

\section{8. Época Medieval}

1511 Cerâmicas islâmicas no Garb setentrional "português": algumas evidências e incógnitas Constança dos Santos / Helena Catarino / Susana Gómez / Maria José Gonçalves / Isabel Inácio / Gonçalo Lopes / Jacinta Bugalhão / Sandra Cavaco / Jaquelina Covaneiro / Isabel Cristina Fernandes / Ana Sofia Gomes 
1525 Contributo para o conhecimento da cosmética islâmica, em Silves, durante a Idade Média Rosa Varela Gomes

1537 Yábura e o seu território - uma análise histórico-arqueológica de Évora entre os séculos VIII-XII José Rui Santos

1547 A encosta sul do Castelo de Palmela - resultados preliminares da escavação arqueológica Luís Filipe Pereira / Michelle Teixeira Santos

1559 A igreja de São Lourenço (Mouraria, Lisboa): um conjunto de silos e de cerâmica medieval islâmica

Andreia Filipa Moreira Rodrigues

1571 O registo material de movimentações populacionais no Médio Tejo, durante os séculos XII-XIII. Dois casos de "sunken featured buildings", nos concelhos de Cartaxo e Torres Novas Marco Liberato / Helena Santos / Nuno Santos

1585 O nordeste transmontano nos alvores da Idade média. Notas para reflexão Ana Maria da Costa Oliveira

1601 Sepulturas escavadas na rocha do Norte de Portugal e do Vale do Douro: primeiros resultados do Projecto SER-NPVD

Mário Jorge Barroca / César Guedes / Andreia Arezes / Ana Maria Oliveira

1619 "Portucalem Castrum Novum" entre o Mediterrâneo e o Atlântico: o estudo dos materiais cerâmicos alto-medievais do arqueossítio da rua de D. Hugo, nํ. 5 (Porto) João Luís Veloso

1627 A Alta Idade Média na fronteira de Lafões: notas preliminares sobre a Arqueologia no Concelho de Vouzela

Manuel Luís Real / Catarina Tente

1641 Um conjunto cerâmico medieval fora de portas: um breve testemunho aveirense Susana Temudo

${ }_{1651}$ Os Lóios do Porto: uma perspetiva integrada no panorama funerário da Baixa Idade Média à Época Moderna em meios urbanos em Portugal

Ana Lema Seabra

1659 O Caminho Português Interior de Santiago como eixo viário na Idade Média Pedro Azevedo

1665 Morfologia Urbana: Um exercício em torno do Castelo de Ourém André Donas-Botto / Jaqueline Pereira

1677 Intervenção arqueológica na Rua Marquês de Pombal/Largo do Espírito Santo (Bucelas, Loures)

Florbela Estêvão / Nathalie Antunes-Ferreira / Dário Ramos Neves / Inês Lisboa

1691 O Cemitério Medieval do Poço do Borratém e a espacialidade funerária na cidade de Lisboa Inês Belém / Vanessa Filipe / Vasco Noronha Vieira / Sónia Ferro / Rodrigo Banha da Silva

1705 Um Espaço Funerário Conventual do séc. XV em Lisboa: o caso do Convento de São Domingos da Cidade Sérgio Pedroso / Sílvia Casimiro / Rodrigo Banha da Silva / Francisca Alves Cardoso

\section{9. Época Moderna e Contemporânea}

1721 Arqueologia Moderna em Portugal: algumas reflexões críticas em torno da quantificação de conjuntos cerâmicos e suas inferências históricas e antropológicas Rodrigo Banha da Silva / André Bargão / Sara da Cruz Ferreira

1733 Faianças de dois contextos entre os finais do século XVI e XVIII do Palácio dos Condes de Penafiel, Lisboa

Martim Lopes / Tomás Mesquita 
1747 Um perfil de consumo do século XVIII na foz do Tejo: O caso do Mercado da Ribeira, Lisboa Sara da Cruz Ferreira / Rodrigo Banha da Silva / André Bargão

1761 Os Cachimbos dos Séculos XVII e XVIII do Palácio Mesquitela e Convento dos Inglesinhos (Lisboa)

Inês Simão / Marina Pinto / João Pimenta / Sara da Cruz Ferreira / André Bargão / Rodrigo Banha da Silva

1775 "Tomar os fumos da erua que chamão em Portugal erua sancta». Estudo de Cachimbos provenientes da Rua do Terreiro do Trigo, Lisboa

Miguel Martins de Sousa / José Pedro Henriques / Vanessa Galiza Filipe

1787 Cachimbos de Barro Caulínitico da Sé da Cidade Velha (República de Cabo Verde)

Rodrigo Banha da Silva / João Pimenta / Clementino Amaro

1801 Algumas considerações sobre espólio não cerâmico recuperado no Largo de Jesus (Lisboa) Carlos Boavida

1815 Adereços de vidro, dos séculos XVI-XVIII, procedentes do antigo Convento de Santana de Lisboa (anéis, braceletes e contas)

Joana Gonçalves / Rosa Varela Gomes / Mário Varela Gomes

1837 Da ostentação, luxo e poder à simplicidade do uso quotidiano: arqueologia e simbologia de joias e adornos da Idade Moderna Portuguesa Jéssica Iglésias

1849 Os amuletos em Portugal - dos objetos às superstições: o coral vermelho Alexandra Vieira

1865 Cerâmicas de Vila Franca de Xira nos séculos XV e XVI Eva Pires

1879 «Não passa por teu o que me pertence». Marcas de individualização associadas a faianças do Convento de Nossa Senhora de Aracoeli, Alcácer do Sal Catarina Parreira / Íris Fragoso / Miguel Martins de Sousa

1891 Cerâmica de Leiria: alguns focos de produção

Jaqueline Pereira / André Donas-Botto

1901 Os Fornos na Rua da Biquinha, em Óbidos Hugo Silva / Filipe Oliveira

1909 A casa de Pêro Fernandes, contador dos contos de D. Manuel I: o sítio arqueológico da Silha do Alferes, Seixal (século XVI) Mariana Nunes Ferreira

1921 O Alto da Vigia (Sintra) e a vigilância e defesa da costa Alexandre Gonçalves / Sandra Santos

1937 O contexto da torre sineira da Igreja de Santa Maria de Loures Paulo Calaveira / Martim Lopes

1949 A Necrópole do Hospital Militar do Castelo de São Jorge e as práticas funerárias na Lisboa de Época Moderna Susana Henriques / Liliana Matias de Carvalho / Ana Amarante / Sofia N. Wasterlain

1963 SAND - Sarilhos Grandes Entre dois Mundos: o adro da Igreja e a Paleobiologia dos ossos humanos recuperados

Paula Alves Pereira / Roger Lee Jesus / Bruno M. Magalhães

1975 Expansão urbana da vila de Cascais no século XVII e XVIII: a intervenção arqueológica na Rua da Vitória no 15 a 17

Tiago Pereira / Vanessa Filipe

1987 Novos dados para o conhecimento do Urbanismo de Faro em época Moderna Ana Rosa 
1995 Um exemplo de Arqueologia Urbana em Alcoutim: o Antigo Edifício dos CTT Marco Fernandes / Marta Dias / Alexandra Gradim / Virgílio Lopes / Susana Gómez Martínez

2007 Palácio dos Ferrazes (Rua das Flores/Rua da Vitória, Porto): a cocheira de Domingos Oliveira Maia

Francisco Raimundo

2021 As muitas vidas de um edifício urbano: História, Arqueologia e Antropologia no antigo Recreatório Paroquial de Penafiel Helena Bernardo / Jorge Sampaio / Marta Borges

2035 O convento de Nossa Senhora da Esperança de Ponta Delgada: o contributo da arqueologia para o conhecimento de um monumento identitário João Gonçalves Araújo / N’Zinga Oliveira

2047 Arqueologia na ilha do Corvo... em busca da capela de Nossa Senhora do Rosário Tânia Manuel Casimiro / José Luís Neto / Luís Borges / Pedro Parreira

2059 Perdidos à vista da Costa. Trabalhos arqueológicos subaquáticos na Barra do Tejo Jorge Freire / José Bettencourt / Augusto Salgado

2071 Arqueologia marítima em Cabo Verde: enquadramento e primeiros resultados do projecto CONCHA

José Bettencourt / Adilson Dias / Carlos Lima / Christelle Chouzenoux / Cristóvão Fonseca / Dúnia Pereira / Gonçalo Lopes / Inês Coelho / Jaylson Monteiro / José Lima / Maria Eugénia Alves / Patrícia Carvalho / Tiago Silva

2085 Trabalhos arqueológicos na Cidade Velha (Ribeira Grande de Santiago, Cabo Verde): reflexões sobre um projecto de investigação e divulgação patrimonial André Teixeira / Jaylson Monteiro / Mariana Mateus / Nireide Tavares / Cristovão Fonseca / Gonçalo C. Lopes / Joana Bento Torres / Dúnia Pereira / André Bargão / Aurélie Mayer / Bruno Zélie / Carlos Lima / Christelle Chouzenoux / Inês Henriques / Inês Pinto Coelho / José Lima / Patrícia Carvalho / Tiago Silva

2103 A antiga fortificação de Quelba / Khor Kalba (E.A.U.). Resultados de quatro campanhas de escavações, problemáticas e perspectivas futuras Rui Carita / Rosa Varela Gomes / Mário Varela Gomes / Kamyar Kamyad

2123 Colónias para homens novos: arqueologia da colonização agrária fascista no noroeste ibérico Xurxo Ayán Vila / José Mạ . Señorán Martín 


\title{
O SÍTIO ARQUEOLÓGICO DE CASTANHEIRO DO VENTO. DA ARQUITECTURA DO SÍTIO À ARQUITECTURA DE UM TERRITÓRIO
}

\author{
João Muralha Cardoso
}

\begin{abstract}
RESUMO
Castanheiro do Vento é um sítio arqueológico com uma ocupação que abrange todo o $3^{\circ}$ milénio e a primeira metade do $2^{\circ}$ a.C. Situa-se no concelho de Vila Nova de Foz Côa, distrito da Guarda e tem sido investigado por uma vasta equipa. Com esta comunicação pretende-se dar a conhecer algumas reflexões sobre a forma de construir em Castanheiro do Vento e partilhar algumas ideias sobre as relações entre esse fazer arquitectura no sítio e a ideia de arquitecturar um espaço maior, um território. Se aceitarmos que construir é uma forma de estar no mundo, a arquitectura terá sempre conexões a esse mundo e consequentemente à sua organização. É importante ter em conta que durante a Pré-história recente, a paisagem do Alto Douro foi sendo alterada por parte de comunidades em processo de consolidação de um sistema agro-pastoril. Este processo de territorialização, levou a uma ocupação diversificada da paisagem. Alguns pontos dessa paisagem foram marcados através da construção de recintos murados, outros, quase que são invisíveis e ainda outros, que ocupam grandes marcadores naturais da paisagem.
\end{abstract}

Palavras-chave: Alto Douro, Pré-história Recente, Arquitectura, Arqueologia da Paisagem.

\begin{abstract}
Castanheiro do Vento is an archaeological site with an occupation that covers the entire 3rd millennium and the first half of the 2nd BC. It's located in the municipality of Vila Nova de Foz Côa, district of Guarda and has been investigated by a vast team. With this paper, we intend to present some reflections on how to build in Castanheiro do Vento and share some ideas on the relationship between doing architecture on the site and the idea of architecting a larger space, a territory. If we accept that building is a way of being in the world, architecture will always have connections to that world and consequently to its organization. It is important to bear in mind that during recent prehistory, the landscape of the Alto Douro was being changed by communities in the process of consolidating an agro-pastoral system. This territorialization process led to a diversified occupation of the landscape. Some points of this landscape were marked by the construction of walled enclosures, others, which are almost invisible and still others, which occupy great natural markers of the landscape.
\end{abstract}

Keywords: High Douro, Late Prehistory, architecture, Landscape Archaeology.

\section{INTRODUÇÃO}

O sítio arqueológico de Castanheiro do Vento (Horta do Douro, Vila Nova de Foz Côa, Guarda), foi identificado por António Sá Coixão em 1983, no âmbito de trabalhos de campo da Associação Cultural Desportiva e Recreativa de Freixo de Numão que, anos mais tarde, levaram à publicação da Carta Arqueológica de Vila Nova de Foz Côa (Coixão 1996). Dois anos depois, encontravam-se reunidas as condições para a apresentação de um projecto de investigação e para o início de intervenções arqueológicas (Cardoso 2012). Genericamente o sítio data do $3^{\circ}$ milénio a.C e primeira metade do $2^{\circ}$ milénio

1. Centro de Estudos de Arqueologia, Artes e Ciências do Património - Universidade de Coimbra / CEAACP - UC;

muralhacardoso@uc.pt 
a.C. As suas campanhas de escavação encontram-se praticamente todas publicadas (veja-se as duas últimas, Muralha, \& alii, 2019 e Muralha, Gomes e Jorge 2020) e muitas leituras do sítio têm sido realizadas (por exemplo, Vale 2011, Carneiro 2011, Cardoso 2010, Carvalho 2006, Jorge 2006) (Figura 1).

Este artigo pretende dar a conhecer algumas reflexões sobre a forma de construir em Castanheiro do Vento e partilhar algumas ideias sobre as relações entre fazer arquitectura no sítio e arquitecturar uma paisagem. Para isso, partimos das constantes acções construtivas ali detectadas, que vão conformando, alterando e mantendo o espaço para as acções que também vão acontecendo na paisagem. Existe uma conexão entre o sítio e a paisagem. A construção do recinto murado de Castanheiro do Vento e a sua constante reconfiguração, terá acontecido dentro de uma matriz de negociação, confronto, diálogo entre indivíduos, entre comunidades e o território que partilham. As comunidades estruturavam-se socialmente a fazer arquitectura ao mesmo tempo que se iam identificando com um território, onde existiam, se organizavam e consolidavam novos sistemas.

\section{ARQUITECTURA DO SÍTIO}

Ao longo dos anos, o processo de escavação em Castanheiro do Vento tem tido um conjunto de objectivos muito diversificados. Foi, desde o primeiro ano de trabalhos, uma escavação onde os alunos de arqueologia se familiarizavam com as técnicas e métodos do trabalho de campo. Foi também palco de reflexões individuais conducentes a trabalhos de investigação académicos de diversos graus (Barbosa 2003, Borges 2003, Vale 2003 e 2011, Cunha 2004, Gaspar 2004, Carvalho 2005, Costa 2007, Queirós 2007, Pinheiro 2008 e Cardoso 2010) mas acima de tudo foi um espaço de diálogo, de trabalho em equipa e de liberdade. A riqueza arqueológica do sítio, levou a equipa de coordenação a pensar sobre assuntos diferentes e a ter liberdade individual para procurar outras abordagens, para reflectir sobre outros assuntos. No entanto a questão das técnicas construtivas e dos materiais de construção, sempre esteve presente. A interacção constante com o sítio e o diálogo sistemático que uma escavação representa, levou o autor deste texto, a partir dos materiais e técnicas que conformam aquele lugar, a pensar em espaços e na sua organização.
O trabalho de campo é um processo constante de reflexão. Quando escavamos, definimos espaços, fotografamos e desenhamos áreas com estruturas e vazios, intervimos num espaço onde contemplamos vestígios de arquitectura, damos sentidos e significados a esse espaço, a essa arquitectura, tornando parte do processo arqueológico de Castanheiro do Vento uma reflexão, precisamente sobre arquitectura.

A construção que se apõe a uma determinada área, é o primeiro passo para transformar essa área em lugar. Emerge uma ideia; a construção/conformação de um espaço, o fazer arquitectura é um processo de transformação de um espaço em lugar, e essa transformação possui um carácter prático, para estas comunidades. Não existe um plano prévio, uma planta pensada, onde todas as áreas de um sítio estejam planeadas, compartimentadas e ocupadas (Cardoso 2010:291, McFadyen 2013:138). A arquitectura, neste contexto preciso, tem de ser olhada e pensada como saber e não como disciplina. É um saber prático, a construção surge pela experiência, "(...) o discurso arquitectónico é gerado através de um envolvimento prático com o ambiente e funciona através de uma rede complexa de acções." (Cardoso 2010:291). Olhemos então para a arquitectura enquanto acção. Aquilo que hoje se nos apresenta, em Castanheiro do Vento, são imagens de acção, de uma acção colectiva, comunitária. De uma acção, provavelmente negociada e representativa das negociações intersubjectivas da comunidade. São imagens que nos propõe uma arquitectura da liberdade, da política, aqui entendida como uma negociação social, interactiva e relacional destas comunidades.

É neste sentido que queremos destacar a habilidade técnica, o gesto técnico e as técnicas de configuração como um saber, e torno a referir, no contexto preciso destas comunidades, como um saber fazendo (Ingold 200o). Este saber fazer remete-nos para actos construtivos, para acções de conformação do sítio, mas acções inseridas num processo contínuo de vivências no local e não inseridas em dinâmicas construtivas. Acções que pertencem a uma matriz social e relacional dessas comunidades. A construção/ conformação do sítio são noções operatórias que ajudam ao processo construtivo da sua identidade social. O acto de elaborar, configurar, manter um espaço torna-se uma actividade recorrente, tanto no tempo como no espaço do sítio e constitui-se como um processo de entrelaçamento das relações sociais daquelas comunidades. A definição opera- 
tiva de arquitectura neste texto é a sua capacidade de interpretar a realidade, o contexto social em que é praticada e o texto que nos pode dar a ler. Negá-la enquanto disciplina, reafirmo no contexto deste trabalho, não pressupõe negar a sua especificidade, a sua criatividade e os momentos de síntese e de projecto. Estes são momentos de uma concepção de arquitectura mais recente.

A arquitectura em Castanheiro do Vento, como criadora de novos e diferentes espaços, não pode ser entendida como estanque. Tomando Heidegger como inspiração (2005:102,109), podemos dizer que o sítio não foi construído para ser habitado, o sítio é habitado porque vai sendo construído. A escavação revela-nos uma constante imbricação de estruturas e de espaços abertos, de modificações e alterações, de materiais construtivos (pedra, terra, madeira) e outros materiais (fragmentos de cerâmica, restos de moinhos, ossos de animais), que tem de ser interpretados como contextos construtivos que terão uma leitura social daquelas comunidades (Cardoso 2010, Vale 2011).

Ao longo dos anos temos conseguido identificar as características principais da forma de construir em Castanheiro do Vento. A primeira característica é ser uma arquitectura modular (Cardoso 2010). A acção construtiva baseia-se em módulos, pelo menos nas grandes linhas que definem o sítio; as quatro linhas de murete. Estes módulos que vistos em conjunto, se assemelham a diagramas permitem uma delineação estrutural do sítio, que em última análise, nunca termina. O tipo de acção construtiva em Castanheiro do Vento não objectiva um resultado, (uma obra construída e terminada), mas sim, resultados contínuos, pois a modulação arquitectónica permite alterações constantes, sem alterar significativamente as estruturas anexas à alteração que se pretende fazer. É interessante notar que o arquitecto catalão, Josep Maria Montaner, refere-se aos diagramas em arquitectura como (...) depósitos dinâmicos de experiências, percepções e intenções" (2017:62). A construção modular em Castanheiro do Vento parece consubstanciar esta ideia. A possibilidade de poder alterar pontualmente o desenho construtivo, deveria acontecer num contexto de intenções comunitárias. O trabalho desenvolvido, os materiais escolhidos, as deposições associadas, como veremos a seguir, seriam acções construtivas plenas de experiências e percepções que construiriam e promoviam a identidade colectiva daquela comunidade (Figura 2).
A segunda característica é ser uma arquitectura de acrescentos. Acrescentos que redefinem espaços, estreitam passagens, ocluem e incorporam estruturas. Tanto a arquitectura modular, como a de acrescentos existem através de diferentes formas de prática e, provavelmente em momentos específicos de tempo. Teremos de admitir que este sítio vai-se construindo, alterando, reformulando de uma forma mais ou menos contínua. Claro que existiram momentos de não construção, momentos de manutenção do lugar, de vivência mais efémera. Mas esta acção construtiva mais ou menos constante em Castanheiro do Vento, incorpora o sítio no processo histórico e identitário destas comunidades (Figura 3).

A terceira característica desta arquitectura parece acentuar esta última ideia; a utilização de materiais e/ou fragmentos de materiais em deposições estruturadas. Ana Vale tem estado atenta a esta situação (Vale 2019). O seu trabalho sobre deposições detectadas em Castanheiro do Vento e a sua relação à arquitectura do sítio oferece-nos um conjunto de observações interessantes. Como exemplo; o caso da deposição encontrada no interior do murete 1 , composta por um fragmento de peso tear e elementos em granito, remete estes elementos para a própria construção do murete. A combinação do granito e da argila com o xisto parece invocar os próprios materiais com que o sítio é feito. Estes elementos, integrados no murete, tornam-se constituintes da própria estrutura, são tanto materiais construtivos, como elementos arquitectónicos. A arquitectura, desta forma, também é deposição e os fragmentos de peças depositados são elementos construtivos, na medida em que organizam, fazem, constituem espaço (Figura 4).

O trabalho no sítio é tão importante como a vivência no local. Aliás, muito provavelmente esta diferença entre estar a viver no sítio e estar a construir o sítio, não existia. O próprio acto de construir é um acto de habitar (Heidegger 2005:109). Teremos de admitir que a construção e a estruturação deste sítio nunca foi um projecto terminado, mas sim um processo em constante configuração. Esta forma de habitar o sítio remete-nos para a ideia de que todo ele é, na sua constante elaboração, um local de tensões sociais dinâmicas. O movimento construtivo que engloba uma conformação modular, acrescentos e deposições estruturadas é um movimento inerente a toda uma comunidade. Um movimento relacional de cariz social que incorpora a elaboração do sítio, 
contrário a um movimento apenas técnico, juntar materiais e construir. Esta conformação de um espaço, acontece no tempo longo. A sua elaboração é um processo social, é uma acção de configuração das relações de sociabilidade. O tempo de construção é um tempo de corporização das próprias normas sociais destas comunidades. Esta relação constante entre pessoas, materiais e espaços, torna a arquitectura de Castanheiro do Vento estruturante de um processo social, desta forma, o sítio nunca foi um objecto terminado, da mesma forma que as relações sociais entre pessoas e entre comunidades nunca cristaliza. A escavação tem demonstrado que o processo de juntar os vários elementos configurativos do sítio parece ser um processo persistente, onde a acção é constante. Assim, a arquitectura compreende todas as acções relacionadas à prática do saber fazer. Considerando esta reflexão, ressalta aqui uma observação importante: Compartimentamos e reduzimos a história da arquitectura pré-histórica, a fases de construção, a momentos de abandono, ao fecho e abertura de estruturas. Tendemos a olhar para as fases construtivas de um sítio e pouco para o acto de construir/fazer arquitectura.

É importante olhar para estas arquitecturas (não só Castanheiro do Vento, mas também Castelo Velho de Freixo de Numão) como um espaço de interacção e interrelações dinâmicas e não apenas, como um contentor delineado por superfícies materiais (estruturas circulares, "bastiões", muretes). O espaço é fundamentalmente social e ao estudarmos formas de organização daqueles espaços, estudamos as formas de agir, relacionar e comunicar destas comunidades. As experiências arquitectónicas são acções, não objectos. Articulam relações humanas, materializam e solidificam uma ordem social e identitária. São espaços vividos. "Architectural space is lived spaced rather than physical space, and lived space always transcends geometry and measurability." (Juhani Pallasmaa 2012:68)

Esta arquitectura, além da sua dimensão técnica e temporal, possui uma dimensão social; a transformação de sítios em lugares com significado na paisagem. As práticas do fazer são acções que fazem parte de um processo de estar no mundo. E este estar no mundo acontece não só no sítio, como na paisagem. Ao longo do $3^{\circ}$ milénio a.C. esta paisagem vai sendo marcada por comunidades com grande mobilidade e em processo de consolidação do sistema agro-pastoril. Esta mobilidade e o processo de territo- rialização que está a acontecer, permitem-nos falar da ideia de arquitecturar um espaço, um território, uma paisagem.

\section{A ARQUITECTURA DA PAISAGEM}

Neste momento torna-se importante deixar de ver apenas o sítio e passar a olhar o mundo, onde o sítio também é. Castanheiro do Vento faz parte da paisagem que o envolve assim como essa paisagem também faz parte de Castanheiro do Vento.

Não só os materiais construtivos estão no sítio (própria pedreira de xisto, veios de quartzo) ou à sua volta (barreiros e nascentes), como as acções construtivas atribuem ao lugar uma certa monumentalidade, tornando a própria colina um lugar monumental (Jorge 2006, Cardoso 2010, Vale 2011) (Figura 5).

Este conceito de colina monumental, pensado por Vítor Jorge, facilmente nos transporta para a ideia de que o próprio sítio poderá ter-se constituído como um dispositivo cénico e plástico, porque ao mesmo tempo que é trabalhado, construído, mantido pela comunidade é também um elemento perdurável na paisagem. É um lugar que fixa as memórias colectivas das comunidades, dando-lhes um sentido de identidade. A sua implantação relembra, transmite e recria a ideia de identidade e organiza a matriz social destas sociedades ainda muito segmentárias.

Torna-se importante neste momento, inserir Castanheiro do Vento no contexto da paisagem e tentar perceber a sua relação com outros sítios arqueológicos. Em trabalhos anteriores $(2010,2017)$ ensaiamos leituras de relações visuais entre Castanheiro do Vento e outros locais. As observações foram interessantes, mas tivemos sempre de adicionar outros parâmetros de estudo para que as conclusões se tornassem mais significativas do que uma cartografia de bacias de visão. Os trabalhos sobre visibilidades e intervisibilidades são importantes, mas têm que ser enquadrados a vários planos; as suas visibilidades imediatas, as conectividades visuais mais longínquas e a própria linha de horizonte que daquele ponto preciso, encerra o mundo. Esta cartografia de visibilidades permite-nos vários níveis de reflexão: colocam na paisagem lugares de observação, dinâmicos e móveis consoante a nossa própria deslocação; colocam no terreno linhas de mobilidade que ao serem percorridas implantam na paisagem nós de passagem sucessivos, e por último, a própria mobilidade coloca na paisagem várias dimensões exis- 
tenciais daquelas comunidades. O conjunto destes níveis de reflexão, transformam este espaço em paisagem vivida, habitada.

O exemplo do sítio arqueológico da Quinta de Alfarela é paradigmático. É um lugar voltado ao rio Douro, perto da foz do rio Sabor. A sua posição visual estratégica é evidente, o sítio "controla" as linhas de água e a fértil várzea da Vilariça. No entanto, a implantação deste lugar e as suas linhas de horizonte e de visibilidade, remetem-no para outros sítios como Senhora do Viso, Castelo de Numão e mesmo Castanheiro do Vento, localizados a mais de $20 \mathrm{~km}$ de distância (Figura 6).

O trabalho publicado em 2010 e continuado mais tarde (2017), chamava a atenção para a importância da mobilidade nestas comunidades e de como esse andar ligava todos os espaços e religava a própria estruturação daquelas comunidades. Neste caso, podemos dar como exemplo o objecto principal deste artigo; o sítio de Castanheiro do Vento. Está geomorfologicamente implantado num grande cabeço oblongo voltado à ribeira da Teja, com grande domínio visual sobre a sua várzea. Tem uma amplitude de horizonte para Sul até à Serra da Marofa e aos grandes batólitos graníticos do Souto. A Norte, olha toda uma vasta área entre as Serras de Ansiães e a Serra do Reboredo, já no distrito de Bragança. Tem uma excelente intervisibilidade com vários sítios arqueológicos a dois níveis. Um primeiro, onde existem sítios que se observam nos planos de paisagem imediatos (Senhora do Viso, Zaralhôa, Raza I e II, Castelo de Numão, São Martinho e Santa Eufémia), e um segundo nível onde os sítios existem num horizonte quase imperceptível (Castelo Velho de Freixo de Numão, Santa Columba, São Jurges e Castelo Velho do Souto). Um outro aspecto importante neste contexto geográfico e geomorfológico é a presença próxima de dois grandes marcadores paisagísticos, duas especificidades geomorfológicas; a Senhora do Viso que polariza imediatamente Castanheiro do Vento a Norte, truncando mesmo a sua visibilidade para nordeste, mas ao mesmo acentuando o sítio arqueológico e São Martinho a nordeste, grande crista quartzítica implantada entre duas colinas, a cota mais baixa, não truncando qualquer visibilidade, mas impondo-se na paisagem e congregando em seu redor, um conjunto de sítios arqueológicos, muitos deles partilhados com o campo de visão de Castanheiro do Vento. Castanheiro do Vento torna-se assim, visível de todos os lados. Esta afirmação não pressupõe que consideremos aquela estação arqueológica como um "lugar central", pois embora seja efectivamente um lugar importante, a sua centralidade é inexistente. A paisagem existe em seu redor, como existe em redor dos outros sítios, com características específicas e diferenciadas. A ideia interessante relacionada a esta imagem de (inter)visibilidades de Castanheiro do Vento, parece ser a ideia da apreensão de uma paisagem. Os construtores daquele sítio percepcionam o mundo incorporando a percepção do lugar onde se está, onde se habita. Não existe um lugar central, um lugar de habitação, um lugar de caça, um lugar de arte, existe um processo constante de integração de uma comunidade numa paisagem e em todas as suas acções. É evidente que cada um daqueles sítios, para aquelas comunidades, é olhado e tratado de forma diferente, mas ao longo do $3^{\circ}$ milénio a.C. e, provavelmente, também ao longo da primeira metade do $2^{\circ}$ milénio a.C., a relação do homem com a paisagem é dispersa, acontecendo em muitos lugares. Não está fixa, presa. O homem vai conhecendo o mundo continuamente através da sua mobilidade, através do tempo de movimento. É um tempo importante pois é um tempo em que estas comunidades estão a consolidar o seu sistema agro-pastoril. É um tempo onde a paisagem vai sendo alterada e as próprias comunidades se vão alterando. Existe uma paisagem que se vai transformando em território. Este processo de territorialização, levou a uma ocupação diversificada da paisagem, onde Castanheiro do Vento como recinto murado, São Martinho como especificidade geomorfológica com ocupação, os sítios da Raza como locais sem delimitações estruturais, são actores constantes, importantes e centrais neste processo, onde cada um teve o seu papel (Figura 7).

Hoje dispomos de uma cartografia de sítios (Coixão 1996; Aubry, Carvalho e Zilhão 1997; Coixão, Cruz e Simão 2009; Cardoso 2010) que nos permite pensar as várias dinâmicas de povoamento que terão acontecido durante esse processo. A diversidade de sítios e a variabilidade de implantações é uma característica; a paisagem foi marcada pela construção de recintos murados, todos implantados em locais proeminentes; pela ocupação de marcadores naturais da paisagem (visíveis a grandes distâncias), mas também por sítios quase invisíveis e por outros sem estruturas delimitativas (Cardoso 2010 e 2019). Temos de perceber os sítios como lugares historicamente constituídos. A escolha de um sítio não é 
um acto isolado, é acima de tudo, um acontecimento social que acontece numa paisagem cheia de significados, de referências a usos antigos desse lugar. A ocupação de um território deverá estar intimamente ligada à biografia dos indivíduos e dos grupos. Essas biografias são feitas de redes de relações e acontecimentos que são inseparáveis dos lugares experienciados, são inseparáveis de uma sequência temporal, constituindo narrativas da identidade humana, constituindo biografias. Os lugares ocupados, são-no com especificidades próprias: um abrigo rochoso, uma parede de xisto com pinturas, uma várzea, um cerro, um pico quartzítico, todos estão integrados numa rede de relações humanas que se estendem tanto no espaço, como no tempo.

Os sítios que emergem desses lugares, através da construção, têm diferentes papéis, diferentes significados. Os recintos murados, implantados em lugares proeminentes estão directamente associados ao processo de consolidação do sistema agro-pastoril, a uma ideia de identidade comunitária e territorial. A sua relação com a paisagem é única, pois não só a sua implantação parece encaminhar o sítio para pontos específicos da paisagem, como vimos anteriormente, como vai configurando várias percepções do território e das estratégias da sua transformação.

Os sítios implantados em características marcantes da geomorfologia, ou como temos vindo a denominá-los de especificidades geomorfológicas, como cristas quartzíticas, batólitos graníticos, grandes elevações integradas em cadeias montanhosas, acentuam o papel identitário da comunidade com um território. Não podemos olhar para estes sítios como "centros" de um território ou como "fronteiras", mas sim como elementos que polarizam a(s) comunidade(s) e as integram numa paisagem. Estas características são pontos nas linhas de horizonte de quase todos os outros lugares. São marcadores, que independentemente do coberto vegetal, são visíveis e que apesar da sua cota elevada ou imponência na paisagem, têm percursos que atingem o seu topo e permitem uma aproximação visual a toda uma paisagem que ao longo do $3^{\circ}$ milénio a.C. começa a ser sentida como pertença das comunidades (Figura 8). Pensamos no monte de São Gabriel e a sua relação com o Vale do Côa. As pinturas esquemáticas aqui encontradas completamente voltadas ao extenso planalto de Algodres e ao vale do Côa (Baptista e Reis 2009:19o, Reis 2012:42), assim como os achados dispersos de cerâmicas encontradas no sopé desta crista quartzítica, remetem-nos para uma "arquitectura do território" baseada na mobilidade destas comunidades. Um território vivido, habitado e percepcionado pelo homem. Os sítios não podem ser interpretados como lugares fixos, contidos na paisagem. São lugares que têm de ser pensados através de um contexto relacional de compromisso com essa paisagem. A arquitectura de um território surge como um processo dialógico, negociado, constitutivo de comunidades que viviam, movimentavam-se e se estruturavam a si próprias ao mesmo tempo que organizavam o "seu" território. "Seu" enquanto habitado, percorrido, vivido.

E os outros sítios (Cardoso 2010, 2017, 2019), sem delimitações estruturais, como muretes, abrigos de rocha ou mesmo características físicas da geomorfologia? O trabalho de campo diz-nos que todos estão relacionados com as especificidades geomorfológicas, ou directamente no seu sopé, ou nas proximidades, ou na sua linha de horizonte. Muitos têm uma visibilidade ampla, mas ao mesmo tempo truncada (estão direccionados) e outros caracterizam-se por estarem próximos a grandes vales abertos e várzeas. Neste momento existe um projecto de investigação em campo que objectiva intervenções arqueológicas neste tipo de sítios. É necessário escavá-los para percebermos os seus elementos configurativos, as suas arquitecturas, as suas materialidades e começarmos a problematizar e a reflectir em conjunto. O projecto, aprovado pela tutela, denomina-se Uma investigação sobre a Pré-história Recente do Vale do Côa. Dinâmicas de uso e ocupação do território, coordenado pelo signatário deste texto, com Mário Reis, António Batarda e Carla Magalhães, do CEAACP e Fundação Côa Parque.

\section{CONSIDERAÇÕES FINAIS}

Ao longo deste texto temos vindo a falar da forma como a arquitectura de um sítio arqueológico, neste caso do recinto murado de Castanheiro do Vento, possui um papel identitário, sedimentando ao mesmo tempo, e através de processos de construção, reconfiguração, manutenção, de negociações e procura de consensos, um sentido de pertença a uma paisagem. Este diálogo constante entre pessoas, lugares e arquitectura faz parte do processo histórico de consolidação do sistema agro-pastoril. O número de recintos e de sítios arqueológicos nesta área, tem de ser entendido num contexto de reconfigu- 
ração das relações entre comunidades e territórios. A estruturação desse território, não existe apenas por existirem sítios, existe pelas mobilidades, pela diversidade dos vários lugares e a variabilidade das suas implantações. Existe por tudo isto e pelo próprio contexto histórico daquelas comunidades. A paisagem vai-se tornando um imbricado de acções, torna-se um contexto intrínseco ao habitar. Os sítios arqueológicos são parte integrante deste contexto, sítios com significantes diferentes que constituem uma imagem das sociabilidades dessas comunidades. Nesta perspectiva os sítios arqueológicos são lugares de acções humanas, integrados num complexo entrelaçado de outros lugares e espaços entre eles: a arquitectura de um território. O estudo desta dinâmica é o estudo das marcas na paisagem do processo de consolidação do sistema agro-pastoril. Percebemos que este processo de territorialização levou a uma ocupação diversificada da paisagem, onde a existência de vários e diferentes sítios com diferentes arquitecturas vão sedimentando um território. O estudo deve ser pensado no tempo longo. Os sítios não correspondem apenas a determinadas categorias, nem á forma como uma comunidade habita uma região. Os sítios são também exemplos de percepção de um território experiencial em oposição a um espaço cartesiano. A percepção humana da paisagem tem de ser um dado de estudo importante para se perceber o tipo de relações espaciais aí existentes. Neste contexto, os sítios/lugares de ocupação não devem ser conceptualizados como locais fechados, encerrados sobre a sua "cultura material", protegendo a sua população do exterior "selvagem". Os lugares fazem parte de uma imensa paisagem, fluída e social, onde os caminhos, as características topográficas, os homens, os animais detêm um papel significante na criação cultural.

O recinto murado de Castanheiro do Vento, a par de outros recintos, marca a paisagem da pré-história recente deste território. Percebemos que a sua arquitectura, a monumentalidade, a especificidade da sua implantação, parecem transformá-lo num dispositivo de âmbito social; a sua conformação depende de dinâmicas identitárias e de negociações intercomunitárias. O estudo da arquitectura em Castanheiro do Vento permite-nos reflectir sobre a dimensão social e temporal dos espaços, das materialidades, e das acções que aconteceram. Percebemos, assim, um sentido de pertença e sentido de território. A dinâmica de construção do sítio; o fazer arquitectura, é uma dinâmica que também encontramos no estudo da paisagem. A mobilidade e a diversidade de sítios, são uma forma de arquitecturar um espaço, um território. São uma impressão dos processos de territorialização e de consolidação do sistema agro-pastoril.

\section{BIBLIOGRAFIA}

AUBRY, Thierry; CARVALHO, António Faustino e ZILHÃO, João (1997) - Arqueologia. In Arte Rupestre e Pré-história do Vale do Côa, Trabalhos de 1995-1996, Lisboa, Ministério da Cultura.

BAPTISTA, António Martinho; REIS, Mário (2009) - Prospecção da Arte rupestre no Vale do Côa e Alto Douro Português: ponto da situação em Julho de 2006. In BEHRMANN, Balbín (ed.) Actas do colóquio "Arte Prehistórico al Aire Libre en el Sur de Europa. Salamanca (15 a 17 de Junho de 2006). Junta de Castilla y Léon, pp. 145-192.

BARBOSA, Rui Mendes (2003) - A estrutura C de Castanheiro do Vento, Análise dos materiais cerâmicos e líticos. Relatório de Seminário de Projecto da licenciatura em Arqueologia apresentada à FLUP. Edição electrónica.

BORGES, Nelson (2003) - A estrutura B de Castanheiro do Vento, Vila Nova de Foz Côa. Relatório de Seminário de Projecto da licenciatura em Arqueologia apresentada à FLUP. Edição policopiada.

CARDOSO, João Muralha (2010) - Castanheiro do Vento (Horta do Douro, Vila Nova de Foz Côa) Um recinto monumental do $3^{\circ}$ e $2^{\circ}$ milénio a.C. Problemática do Sítio e das suas Estruturas à Escala Regional, Palma de Maiorca, Vessants, arqueologia i cultura.

CARDOSO, João Muralha (2012) - Castanheiro do Vento: Uma historiografia de percursos interpretativos. In Sanches, M., Cunha-Ribeiro, J.P. e Monteiro-Rodrigues, S. (eds). Discursos em Arqueologia. Textos oferecidos ao Professor Vitor Oliveira Jorge. Coimbra-Porto. CEAUCP, pp. 67-94.

CARDOSO, João Muralha (2017) - Let's walk in the wild side! Comparing sites in the Landscape. In Ana Vale, Joana Alves-Ferreira, Irene Garcia-Rovira (eds), Rethinking Comparison in Archaeology, Newcastle: Cambridge Scholars Publishing, pp. 108-128.

CARDOSO, João Muralha (2019) - Castelo Velho de Freixo de Numão. Um sítio, uma paisagem. In. Susana Soares Lopes (ed). Olhares sobre Castelo Velho de Freixo de Numão: Revisitar um Recinto Pré-histórico do Alto Douro Português, DigitAR, 1, Coimbra, Imprensa da Universidade de Coimbra, pp. 51-94.

CARNEIRO, Ângela (2011) - As cerâmicas do terceiro e segundo milénio a.C. de Castanheiro do Vento (Horta do Douro, Vila Nova de Foz Côa). In Actas do V Congresso de Arqueologia Interior Norte e Centro de Portugal, Porto, Caleidoscópio, DRC-N. pp. 187-218. 
CARVALHO, Bárbara (2005) - O Desenho na Escavação de Castanheiro do Vento (Vila Nova de Foz Côa). Relatório de Seminário de Projecto Licenciatura em Arqueologia, apresentado à FLUP, Porto. Edição policopiada.

COIXÃO, António Sá (1996) - Carta Arqueológica do Concelho de Vila Nova de Foz Côa, Vila Nova de Foz Côa, Câmara Municipal de Vila Nova de Foz Côa.

COIXÃO, António Sá; CRUZ, Simão (2009) - Carta Arqueológica do Concelho de Mêda, Coimbra, Câmara Municipal de Mêda.

COSTA, Cláudia (2007) - Zooarqueologia e tafonomia de Castanheiro do Vento. Dissertação de mestrado apresentada à Faculdade de Ciências Humanas da Universidade do Algarve. Edição policopiada.

CUNHA, Gustavo (2004) - Contributo para o conhecimento das técnicas de construção de Castanheiro do Vento (Horta do Douro, Vila Nova de Foz Côa). Relatório de Seminário de Projecto da licenciatura em Arqueologia apresentada à FLUP. Edição electrónica.

GASPAR, Clara (2004) - Um Espaço Específico de Castanheiro do Vento (Vila Nova de Foz Côa). A Estrutura D - Materiais e Ocupação. Relatório de Seminário de Projecto da licenciatura em Arqueologia apresentada à FLUP. Edição electrónica.

HEIDEGGER, Martin (2005) - Building, Dwelling, Thinking. In Neil Leach (ed.) Rethinking Architecture, a reader in Cultural Theory. Routledge, New York, pp. 100-108.

INGOLD, Tim (200o) - The Perception of the Environment, Essays in livelihood, dwelling and skill, Londres, Routledge.

JORGE, Vítor (2006) - Breve reflexão sobre alguns problemas das Arquitecturas Pré-históricas. In Actas da 10. Mesa-Redonda da Primavera, TERRA: Forma de Construir, Arquitectura-Antropologia-Arqueologia, Lisboa-Vila Nova de Cerveira, Argumentum, Escola Superior Galaecia, pp. 106-111.

McFADYEN, Lesley (2013) - Designing with living - a contextual archaeology of dependent architecture. In A. Alberti, A. Jones and J. Pollard, J., Archaeology after Interpretation. Walnut Creek: Left Coast Press, 135-150.

MONTANER, Josep Maria (2017). Do diagrama às experiências, rumo a uma arquitectura de ação. São Paulo. Gustavo Gili.

MURALHA, João; GOMES, Sérgio; VALE, Ana e JORGE, Vítor (2019) - "Relatório dos trabalhos arqueológicos em Castanheiro do Vento/2018”, Côavisão. Cultura e Ciência, 21, 39-47.

MURALHA, João, GOMES, Sérgio e JORGE, Vítor (2020) - “A Intervenção Arqueológica de 2019 em Castanheiro do Vento”, Côavisão. Cultura e Ciência, 22, 155-162.
PALLASMAA, Juhanni (2012) - The Eyes of the Skin. Architecture and Senses. Chichester. John Willey and Sons Ltd Publications, $3^{\text {rd }}$ Edition.

PINHEIRO, Rui (2008) - Cerâmica do Bastião I de Castanheiro do Vento. Palma de Maiorca, Vessants, Arqueologia i Cultura.

QUEIRÓS, Adélia (2007) - Contributos para o estudo da estrutura sub-circular $n^{\circ} 3$ do sítio pré-histórico de Castanheiro do Vento (Horta do Douro, Vila Nova de Foz Côa). Relatório de Seminário de Projecto da licenciatura em Arqueologia apresentada à FLUP. Edição electrónica.

REIS, Mário (2012) - Mil Rochas e tal!: Inventário dos Sítios da Arte Rupestre do Vale do Côa. Portugália, Nova Série, vol. 33, Porto, DCTP-FLUP, pp. 5-72.

VALE, Ana (2003) - Castanheiro do Vento (Horta do Douro, Vila Nova de Foz Côa) Contributo para o Estudo dos Resultados das Primeiras Campanhas de Trabalho 1998-20oo. Dissertação de mestrado, Faculdade de Letras da Universidade do Porto. Edição policopiada.

VAlE, Ana (2011) - Modalidades de Produção de Espaços no Contexto de uma Colina Monumentalizada: o sítio pré-histórico de Castanheiro do Vento, em Vila Nova de Foz Côa. Dissertação de doutoramento, Faculdade de Letras da Universidade do Porto. Edição policopiada.

VALE, Ana (2019) - Depositions, Assemblages and relationships in Portugues Late Prehistory. In Valera (ed.) Fragmentation and Depositions in Pre and Proto-Historic Portugal. The Case of the Walled Enclosure of Castanheiro do Vento. Lisboa, Núcleo de Investigação Arqueológica (NIA) Era Arqueologia, pp. 31-46. 


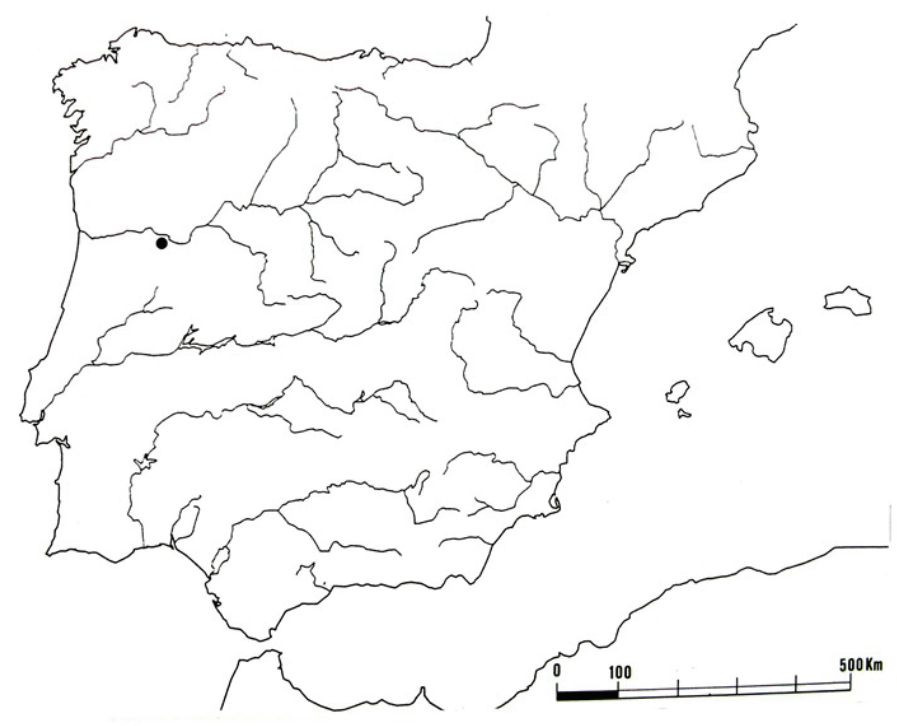

Figura 1 - Localização de Castanheiro do Vento no contexto da Península Ibérica.

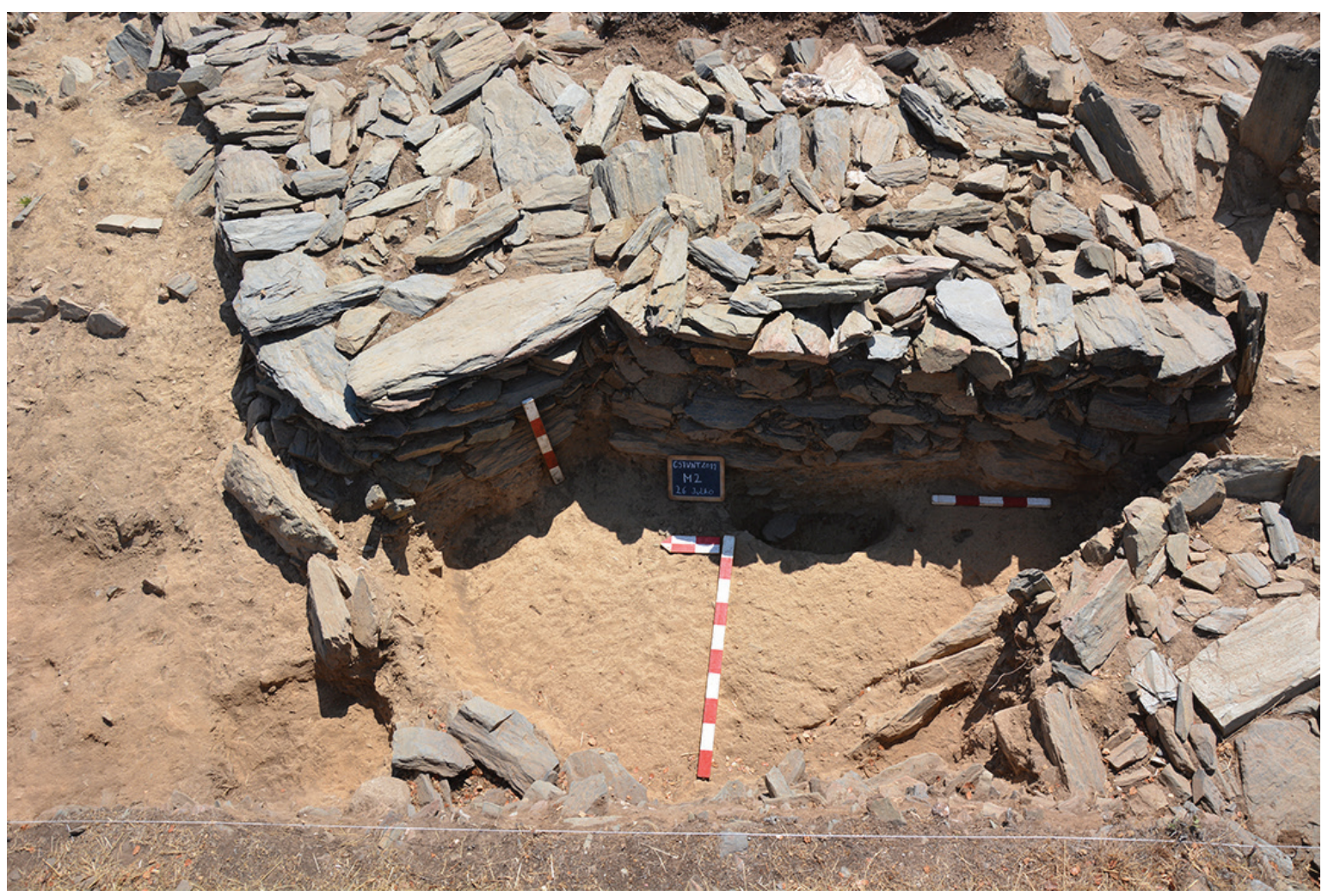

Figura 2 - Exemplo da arquitectura modular em Castanheiro do Vento. A área Sul do Bastião L encosta perfeitamente no troço de murete. 


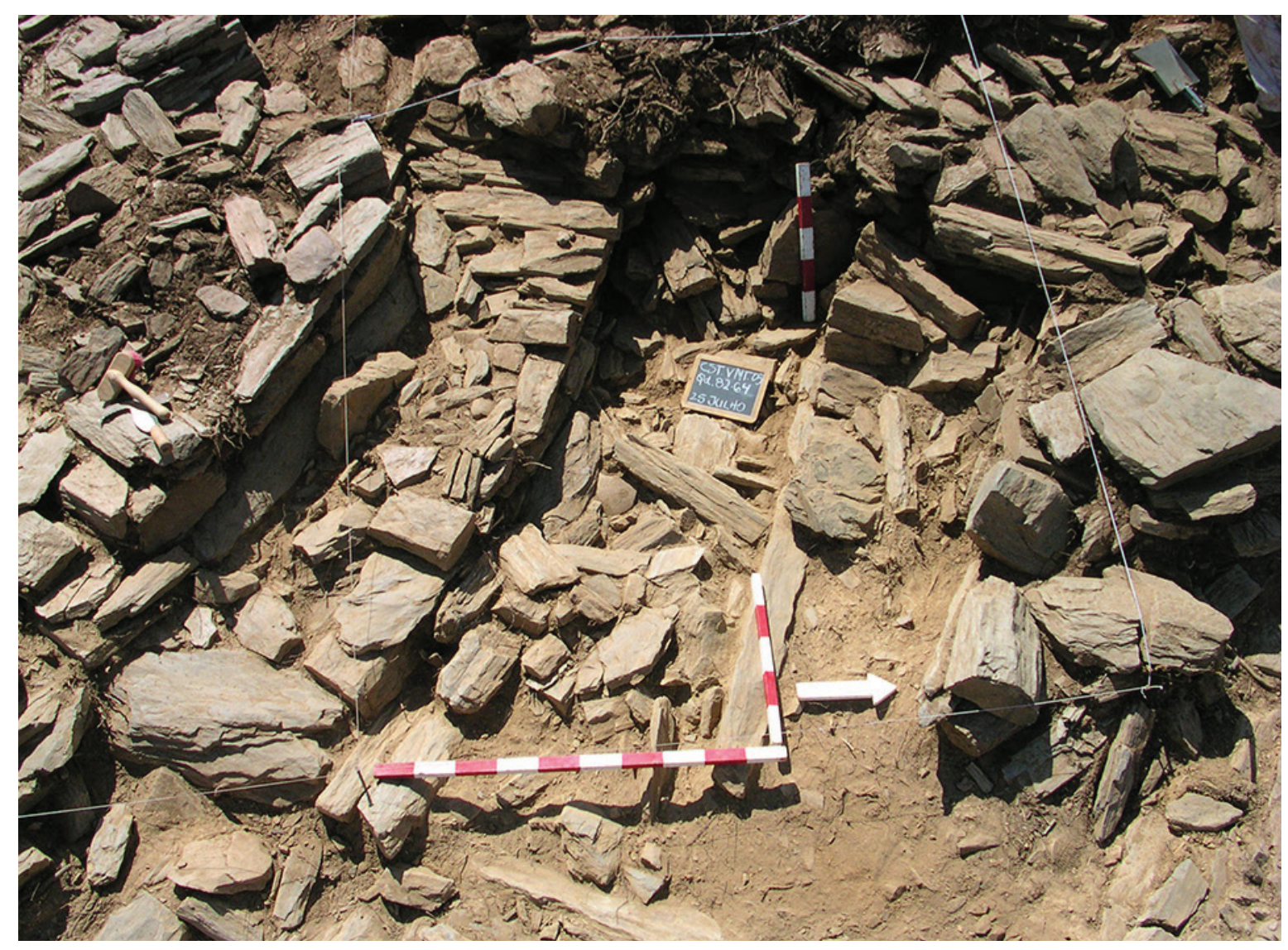

Figura 3 - Exemplo da arquitectura de acrescentos em Castanheiro do Vento, neste caso um estreitamento da passagem 5 , localizada no recinto anexo.

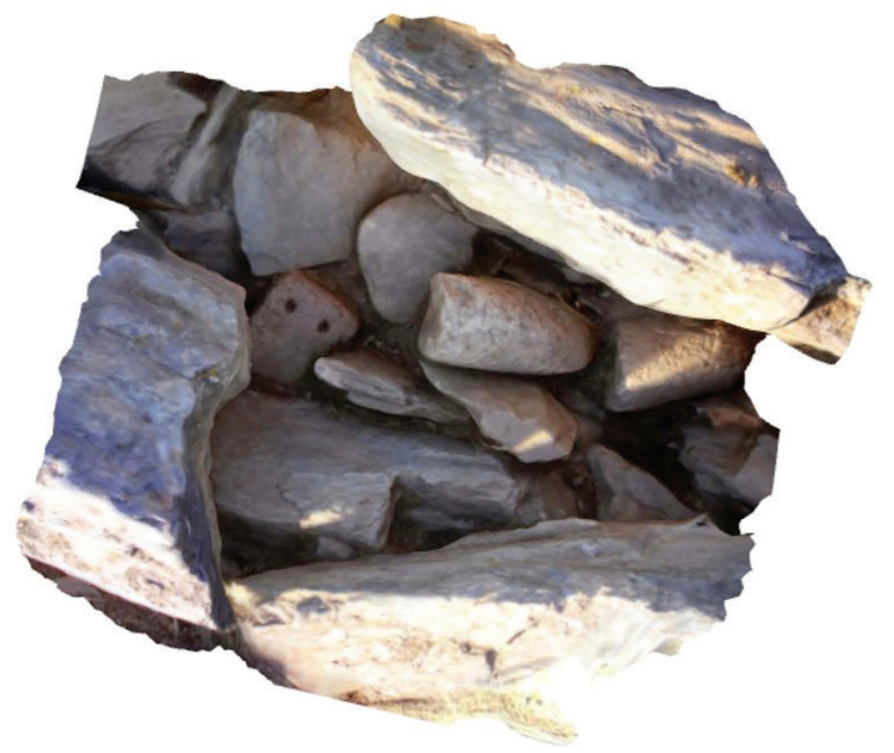

Figura 4 - Exemplo de uma deposição; um fragmento de um peso de tear e de um fragmento de um movente em granito no interior do murete 1. 


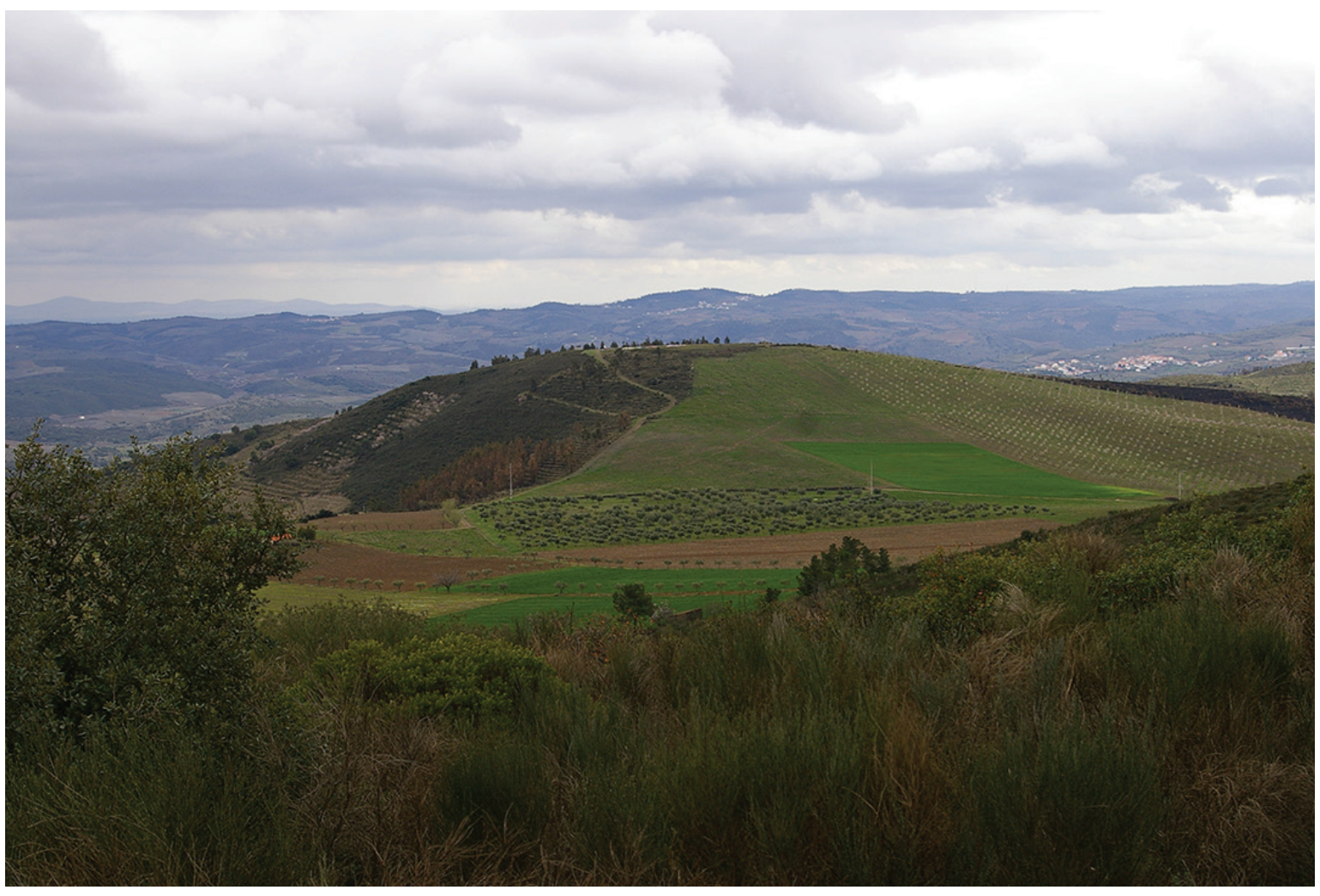

Figura 5- Castanheiro do Vento visto de Norte.

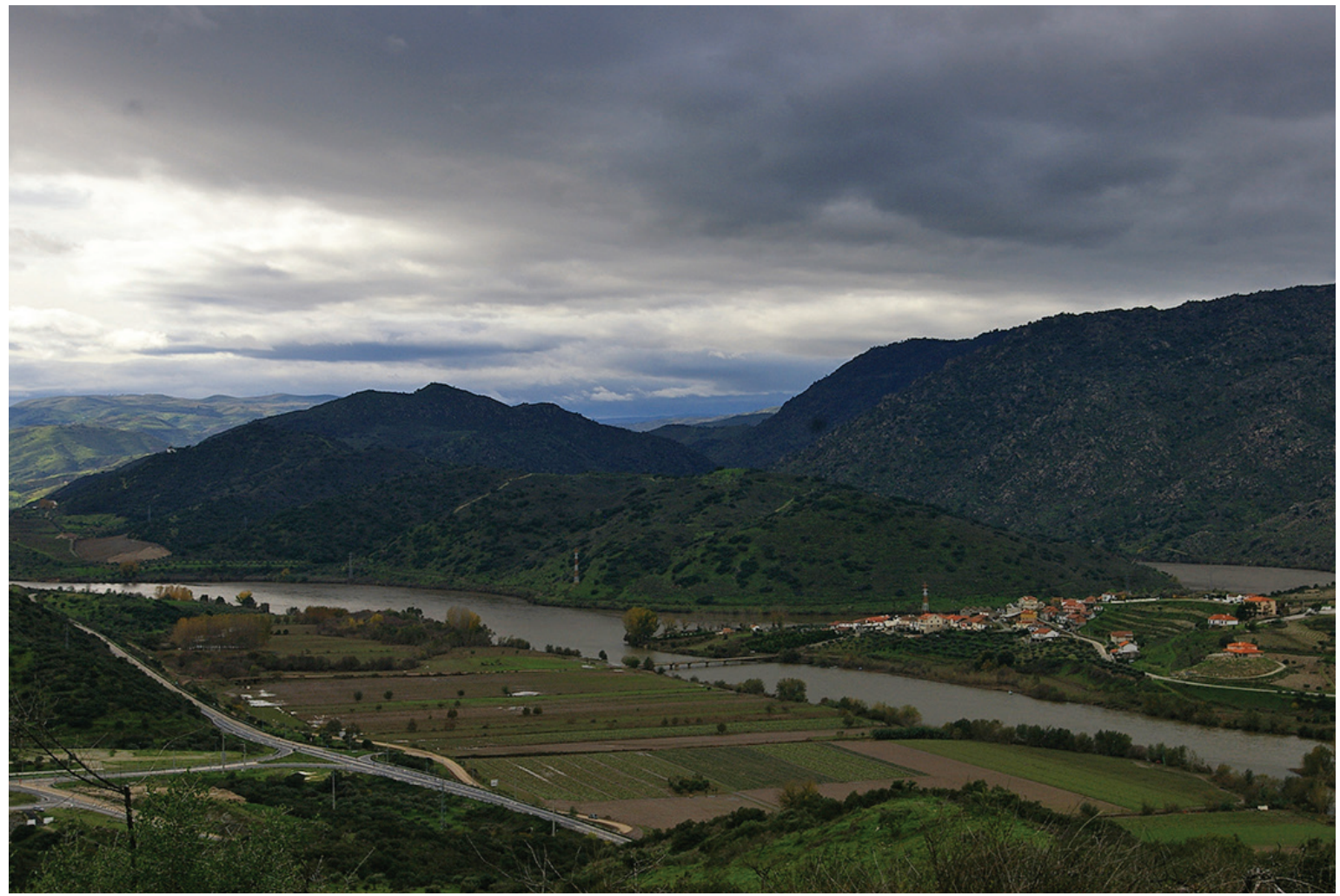

Figura 6 - Ao centro da imagem a Quinta de Alfarela, a uma cota inferior dos montes que estão por trás. É visível a sua implantação em relação à foz do rio Sabor. 


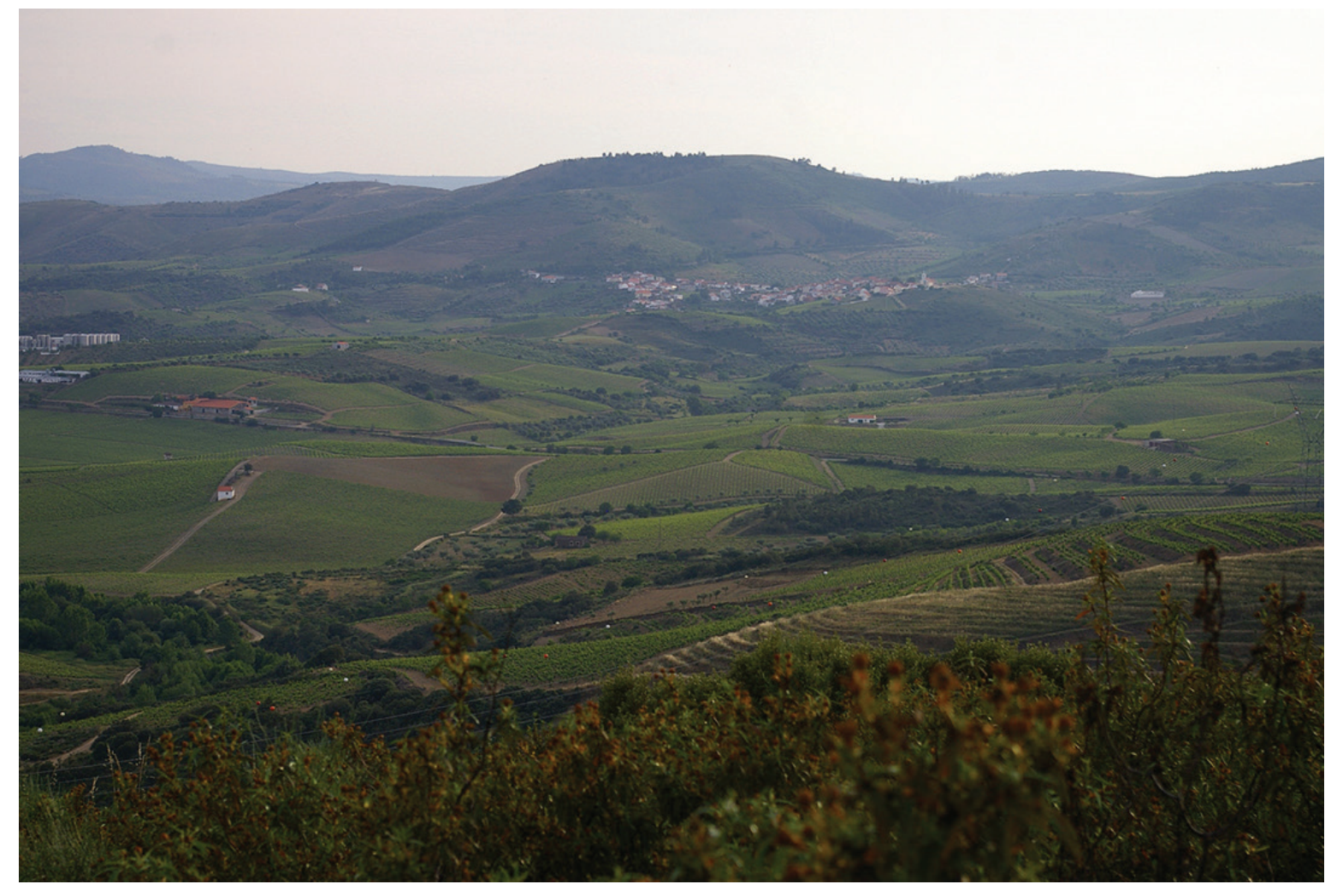

Figura 7 - Castanheiro do Vento visto do sítio da Zaralhôa a nordeste.

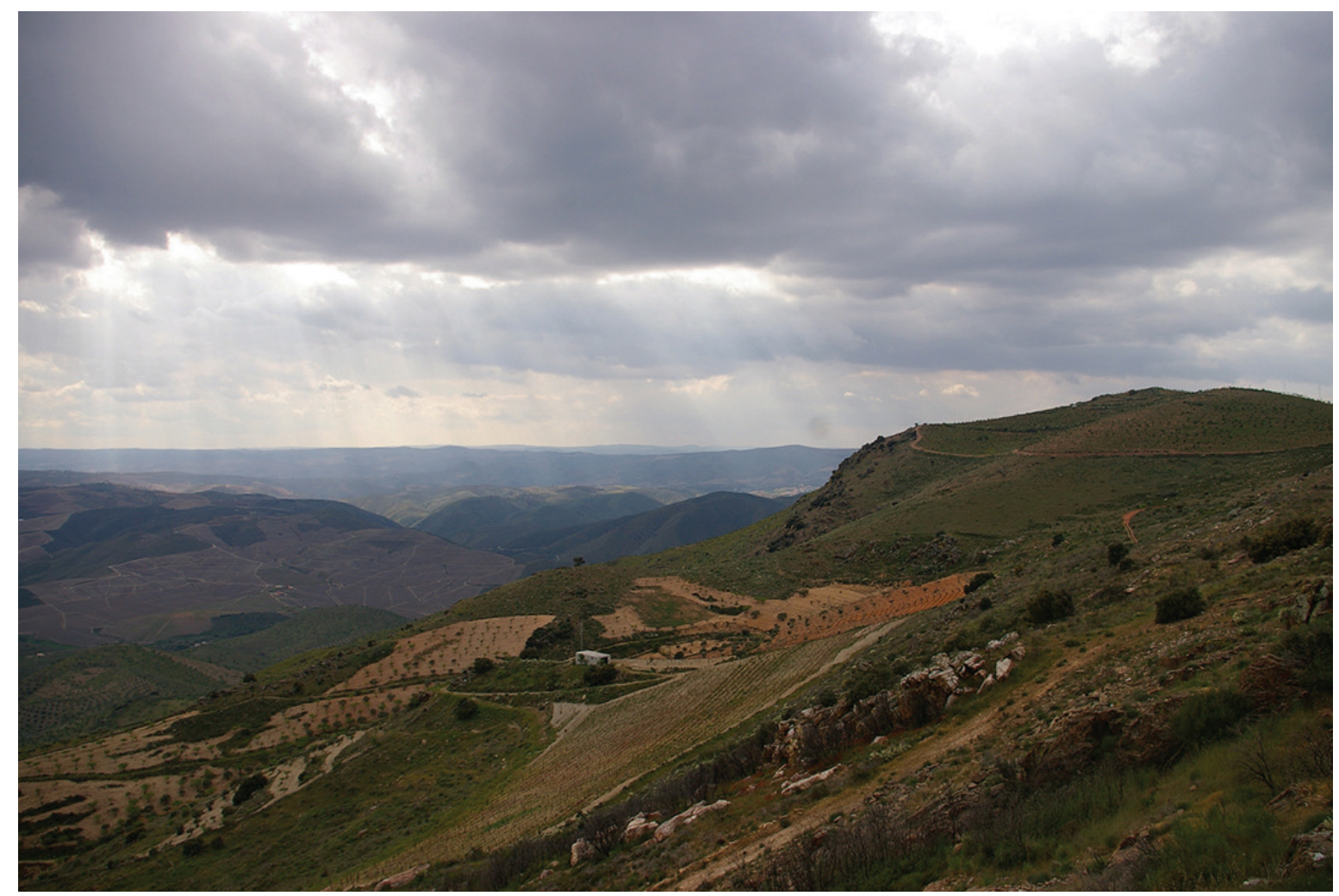

Figura 8 - O sítio arqueológico de São Gabriel. Virado ao vale do Côa (do lado esquerdo da imagem), existe o painel pintado. 



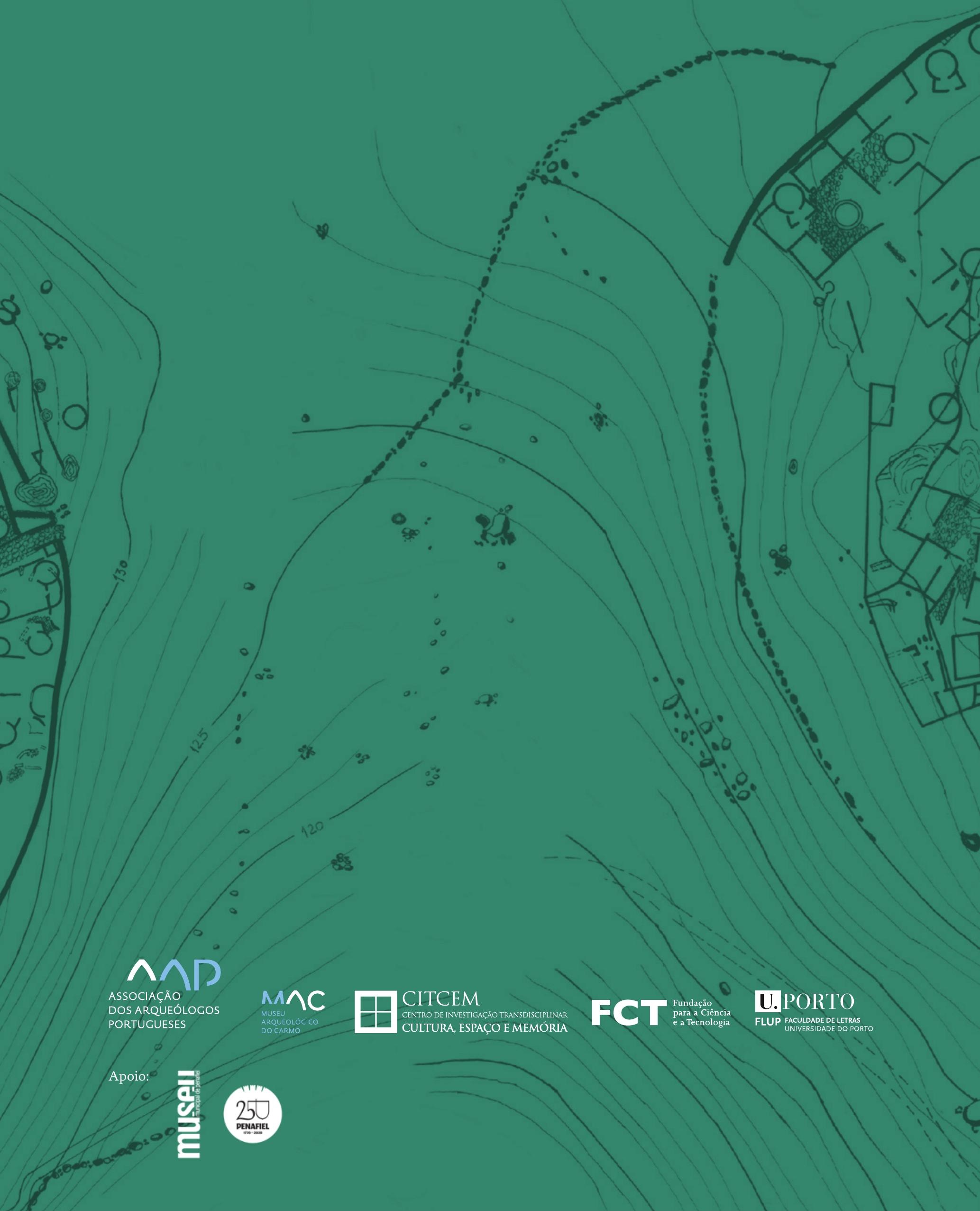

